\title{
NIEDOWARTOŚCIOWANIE PIERWOTNYCH OFERT PUBLICZNYCH W ŚWIELE KONCEPCJI TEORETYCZNYCH
}

\section{WSTĘP}

Jedna z metod pozyskiwania kapitału na rozwój, jak również popularnym sposobem wyjścia dotychczasowych udziałowców z inwestycji w spółkę jest przeprowadzenie pierwotnej oferty publicznej akcji (IPO - Initial Public Offering). Polega ona na zbyciu części istniejących lub nowo wyemitowanych akcji zainteresowanym inwestorom instytucjonalnym lub indywidualnym i późniejszym wprowadzeniu ich na regulowany rynek akcyjny. Często obserwowanym zjawiskiem dotyczącym wprowadzania akcji do obrotu jest różnica pomiędzy wyceną wartości spółki oszacowanej na potrzeby oferty a wyceną dokonaną przez aktywnych uczestników rynku giełdowego, wyrażającej się w cenie akcji w dniu pierwszego notowania debiutującej spółki.

Liczne badania przeprowadzone na przestrzeni ostatnich kilkudziesięciu lat jednoznacznie wskazuja na występowanie niedowartościowania pierwszych ofert publicznych. Oznacza to, że cena emisyjna akcji była niższa od ceny z pierwszego notowania na rynku akcyjnym. Przeciętny poziom stóp zwrotu z jednodniowej inwestycji w akcje spółki debiutującej wyniósł od kilku do kilkudziesięciu procent w zależności od badanego rynku. Rynki uznawane za wysoko rozwinięte wykazują znacząco niższy poziom niedowartościowania IPO niż rynki słabo rozwinięte oraz rozwijające się ${ }^{1}$. Wyniki pierwszych badań empirycznych wskazujące na występowanie niedowartościowania stały się podstawą do formułowania pierwszych teorii próbujących wyjaśnić to zjawisko, jak i zidentyfikować czynniki mogące mieć wpływ na jego skalę. Natomiast weryfikacja nowo powstałych koncepcji teoretycznych stała się przedmiotem kolejnych badań prowadzonych nad tym zjawiskiem.

Celem niniejszego artykułu jest sprawdzenie, które z teorii próbujących wytłumaczyć zjawisko niedowartościowania akcji w ramach publicznych ofert znajdują swoje potwierdzenie na polskim rynku akcji. Realizacja celu została dokonana poprzez badanie przeprowadzone na próbie 200 ofert publicznych dokonanych na Giełdzie Papierów Wartościowych w Warszawie w latach 2007-2016. Wyniki badania poprzedza przegląd teorii odnoszących się do zjawiska, które leżą u podstaw sprawdzanych w badaniu hipotez.

${ }^{1}$ R. Briston, R. Jelic, The choice of privatization method and the financial performance of newly privatized firms in transition economies, „Journal of Business, Finance and Accounting” 30, 2003. 


\section{NIEDOWARTOŚCIOWANIE PIERWOTNYCH OFERT PUBLICZNYCH W POGLĄDACH TEORETYCZNYCH}

\section{Klasyfikacja teorii według Alexandra Ljungqvista ${ }^{2}$}

Przedstawiona poniżej klasyfikacja ma charakter rozłączny, co oznacza, że jedna teoria może zostać zaliczona w poczet więcej niż jednej grup teorii. Zgodnie z klasyfikacją wyróżnia się cztery grupy koncepcji teoretycznych. Pierwsza z nich opiera się na zjawisku asymetrii informacji zachodzącym pomiędzy emitentami a inwestorami lub poszczególnymi grupami inwestorów. Kolejna skupia się na czynnikach związanych z kontrolą nad przedsiębiorstwem dokonujacym emisji i ich wpływie na cenę emisyjną. A. Ljungqvist wyodrębnia także grupę teorii związana z czynnikami instytucjonalnymi. Ostatnia z grup teorii dotyczy czynników behawioralnych, wskazując nieracjonalne zachowania uczestników rynku jako kluczowe w występowanie zjawiska niedowartościowania.

\subsection{Teorie związane $z$ asymetrią informacji}

Jest to grupa koncepcji odnosząca się do przypadku, w którym emitent świadomie ustala cenę $\mathrm{w}$ ofercie publicznej poniżej wartości wewnętrznej. Najpopularniejszym modelem $\mathrm{w}$ zakresie teorii związanych $\mathrm{z}$ asymetria informacji pozostaje koncepcja Kevina Rocka ${ }^{3}$. Wprowadza ona pojęcie winner's curse (,klątwa zwycięzcy”), które dotyczy różnego poziomu informacji posiadanych przez inwestorów. Zgodnie z teorią rynek dzieli się na uczestników lepiej (w założeniu inwestorów instytucjonalnych) i gorzej poinformowanych (inwestorzy indywidualni), co sprawia, że jedna z grup potrafi efektywniej wycenić wartość danej oferty. W efekcie lepiej poinformowani inwestorzy obejmuja większy udział w emisjach charakteryzujących się wysoka jakością, a z kolei grupa o bardziej ograniczonym dostępie do informacji zostaje wyparta przez popyt zgłaszany przez pierwsza grupę i biorą udział w ofertach niższej jakości. W konsekwencji występuje znacząca różnica w uzyskanych stopach zwrotu przez obie grupy inwestorów na korzyść pierwszej z nich. Należy podkreślić, że opisana sytuacja zakłada zastosowanie proporcjonalnej redukcji zapisów w momencie wystapienia warunków nadsubskrypcji.

Kolejna koncepcje oparta na zjawisku asymetrii informacji na rynkach finansowych przedstawili Lawrence Benveniste i Paul Spindt ${ }^{4}$. Jej główne założenie stanowiło uznanie niedoszacowania IPO jako zachęty dla dobrze poinformowanych inwestorów do ujawnienia posiadanych przez nich informacji. Według autorów koncepcji pewne grupy inwestorów potrafia efektywniej szacować wartość wewnętrzną akcji od pozostałych uczestników rynku, w tym również samych emitentów. Proces budowy księgi popytu jest wtedy wykorzy-

\footnotetext{
${ }^{2}$ A. Ljungqvist, IPO Underpricing: Empirical Corporate Finance, NYU Press, New York 2004.

${ }^{3}$ K. Rock, Why New Issues Are Underpriced, „Journal of Financial Economics” 15, 1986.

${ }^{4}$ L. M. Benveniste, P. A. Spindt, How investment bankers determine the offer price and allocation of new issues, „Journal of Financial Economics” 24, 1989.
} 
stywany jako narzędzie pozwalające emitentom na zapoznanie się z akceptowalnym dla inwestorów poziomem ceny za akcję. Dochodzi w takim momencie do ciekawej sytuacji, ponieważ inwestorzy z naturalnych powodów nie sa skorzy do ujawnienia faktycznej wartości akcji, dlatego niedowartościowanie IPO pełni rolę rekompensaty za podzielenie się tą informacją z emitentem. Pozwala to na etapie budowy księgi popytu (ang. book bulding) przeprowadzić alokację akcji głównie między inwestorów gotowych wyjawić rzeczywiste wyceny akcji.

Inną z teorii wiążących zjawisko asymetrii informacji z ponadprzeciętnymi stopami zwrotu zaproponował Ivo Welch ${ }^{5}$. Założył on, że asymetria informacji zachodzi pomiędzy inwestorami a emitentami. W tej sytuacji niedowartościowanie IPO sygnalizuje jakość emitującego akcje. Zatem im większa pozytywna różnica pomiędzy wartością wewnętrzną a ceną w ofercie, tym wyższa jakość oferty. Wiąże się z tym wprowadzone przez Welcha określenie money left on the table (,pieniądze pozostawione na stole”). Określenie to odnosi się do kosztu utraconych korzyści, które ponoszą dotychczasowi udziałowcy na rzecz nowych akcjonariuszy. Na poniesienie tych kosztów nie każdy emitent może sobie pozwolić, dlatego wystapienie tego zjawiska może wskazywać na dobra jakość oferującego akcje. Koszty te zwykle rekompensuje się poprzez kolejne emisje, których warunki są korzystniejsze dla spółki.

\subsection{Teorie odnoszące się do kontroli nad przedsiębiorstwem}

Druga grupa teorii odnosi się do kontroli i własności, kwestii mających bardzo duże znaczenie w przypadku ofert publicznych. Transfer kontroli jest głównym kosztem niefinansowym po stronie dotychczasowych właścicieli, a niedowartościowanie pierwszej oferty publicznej może zostać wykorzystane jako narzędzie pozwalające wywierać wpływ na alokację akcji pomiędzy inwestorów. Poniżej omówione zostaną dwie najpopularniejsze koncepcje wiążące zjawisko natychmiastowych stóp zwrotu z zagadnieniem kontroli nad przedsiębiorstwem.

Pierwsza z nich, zaproponowana przez Michaela Brennana i Jamesa Fran$\mathrm{ksa}^{6}$, odwołuje się do dążenia przez dotychczasowych zarządzających do utrzymania kontroli nad przedsiębiorstwem, będącej dla nich źródłem prywatnych korzyści. Im wyższy poziom niedowartościowania IPO, tym wyższy popyt zgłaszany przez inwestorów. Im wyższy popyt, tym większe możliwości racjonowania akcji między inwestorów. Pozwala to zarządowi na dużą swobodę w alokacji niedużych pakietów akcji pomiędzy inwestorów, co w konsekwencji prowadzi do znacznego rozdrobnienia akcjonariatu. Natomiast w sytuacji, gdy akcje znajdują się w posiadaniu szerokiej grupy akcjonariuszy o niewielkim udziale, kontrola poczynań zarządu pozostaje mocno ograniczona. Należy zaznaczyć, że powyższa teoria opiera się na silnym założeniu, że w sytuacji nad-

\footnotetext{
${ }^{5}$ I. Welch, Seasoned offerings, imitation costs and thee underpricing of IPO, „The Journal of Finance" 44, 1989, s. 421-449.

${ }^{6}$ M. Brennan, J. Franks, Underpricing: ownership and control in initial public offerings of equity securities in U.K, „Journal of Financial Economics” 45, 1997.
} 
subskrypcji przydział akcji nie następuje przy zastosowaniu proporcjonalnej redukcji.

Z kolei teoria Neila Stoughtona i Josefa Zechnera ${ }^{7}$ podchodzi do zagadnienia kontroli od strony właścicieli, a nie zarządzających, jak to było w omawianej wcześniej koncepcji. Zaproponowany model wskazuje na wpływ efektywnego monitorowania działań zarządu na wartość spółki. Dlatego przeprowadzenie oferty publicznej akcji po cenie niższej od ich wartości wewnętrznej ma stanowić zachętę do objęcia większego pakietu akcji przez inwestora, który będzie uważnie kontrolował zarząd. Pozwoli to na wzrost wartości przedsiębiorstwa, a tym samym przysporzy korzyści majątkowych pozostałym, drobnym akcjonariuszom.

\subsection{Teorie związane z czynnikami instytucjonalnymi}

$\mathrm{W}$ odniesieniu do polskiego rynku omawiana grupa teorii nie ma większego znaczenia, dlatego pozostanie tylko zarysowana. Najczęściej przytaczanym jest model stworzony przez Seha Tinica ${ }^{8}$, w którym emitenci z premedytacja ustalają cenę $\mathrm{w}$ ofercie poniżej wartości rynkowej w celu uniknięcia ewentualnych procesów sądowych mogących wynikać z wysokich spadków cen na wczesnym etapie notowań. Jednak powyższa sytuacja dotyczyć może przede wszystkim Stanów Zjednoczonych, gdzie prawo obejmuje specjalną ochrona inwestorów, a nie dotyczy Polski.

\subsection{Teorie wywodzące się z finansów behawioralnych}

$\mathrm{W}$ ostatnich latach coraz więcej miejsca $\mathrm{w}$ badaniach prowadzonych nad rynkami finansowymi znajduje analiza wpływu czynników psychologicznych na zachowania inwestorów. W odniesieniu do pierwszych ofert publicznych i ich niedowartościowania dominuje pogląd o nieefektywnym rynku i nadmiernie optymistycznych inwestorach. Pogląd ten stał się punktem wyjścia teorii zaproponowanej przez trzech badaczy: Alexandra Ljungqvista, Rajdeepa Sigha i Vikrama Nandę ${ }^{9}$, którzy przyczyn występowania ponadprzeciętnych stóp zwrotu dopatrywali się w nadmiernym entuzjazmie inwestorów, zwłaszcza indywidualnych, którzy wkrótce po debiucie zgłaszaja znaczny popyt na akcje, co winduje ich cenę powyżej ich wartości wewnętrznej. Autorzy koncepcji zwracają uwagę, że przedstawiona sytuacja może być wykorzystywana przez emitentów do maksymalizacji wpływów z emisji za sprawą ustalenia wysokich cen w ofercie, czasem powyżej ich faktycznej wartości.

Zachowania inwestorów na rynkach finansowych leżą również u podstaw teorii przedstawionej przez Edwarda Millera ${ }^{10}$. Przedmiotem jego badań było

\footnotetext{
${ }^{7}$ N. M. Stoughton, J. Zechner, IPO mechanisms monitoring and ownership structure, „Journal of Financial Economics" 49, 1998.

${ }^{8}$ S. M. Tinic, Anatomy of IPO of common stock, „Journal of Finance” 43, 1989.

${ }_{9}$ A. Ljungqvist, V. Nanda, R. Singh, Hot markets, investor sentiment and IPO pricing, „Journal of Business" 79, 2006.

${ }^{10}$ E. Miller, Long Run Underperformance of Initial Public Offerings: An Explanation, University of New Orleans, Department of Economics and Finance Working Papers, New Orleans 2000.
} 
ryzyko, niepewność i rozbieżność opinii potraktowane jako czynniki wpływające na zmiany cen rynkowych. W przypadku pierwotnych ofert publicznych odnosił się właśnie do rozbieżności opinii jako determinanty cen na wczesnym etapie notowań, kiedy to popyt zgłaszany przez hurraoptymistycznych inwestorów podnosi cenę akcji. Natomiast w długim okresie rozbieżność opinii jest niwelowana, a cena rynkowa zaczyna dążyć do wartości wewnętrznej danej akcji. Jest to koncepcja odnoszaca się do długoterminowych stóp zwrotu i warto zaznaczyć, że w efekcie jej założeń oferty publiczne powinny charakteryzować się ujemnymi stopami zwrotu w dłuższym horyzoncie czasowym, co znalazło odzwierciedlenie w wielu badaniach empirycznych.

Kolejna z teorii, zakładając nieracjonalność zachowań uczestników ryn$\mathrm{ku}$, zaprezentowana została w pracy Why has IPO underpricing changed over time? autorstwa Tima Loughrana i Jaya Rittera ${ }^{11}$. Jednakże w przeciwieństwie do dwóch wcześniej przytoczonych modeli, T. Loughran i J. Ritter owa nieracjonalność przypisuja emitentom, a nie inwestorom. Podstawę do sformułowania omawianej koncepcji stanowiła teoria perspektywy.

Należy zaznaczyć, że opisane powyżej teorie opracowane zostały w większości przez badaczy amerykańskich i dotyczyły tamtejszego rynku. Wielu autorów podkreśla fakt, że rynek pierwszych ofert publicznych dość istotnie zmieniał się w czasie, a co za tym idzie - czynniki (a także wielkość ich wpływu) mające wpływ na stopy zwrotu przy okazji debiutu również ewoluowały. W latach osiemdziesiątych średni poziom niedowartościowania pierwszych ofert publicznych akcji wynosił około 7\%, na co wpływ miała przede wszystkim asymetria informacji ${ }^{12}$. Z kolei w końcówce lat dziewięćdziesiątych, wiążących się z bańką internetową na amerykańskim rynku akcji, niedowartościowanie wzrosło już do poziomu kilkunastu procent. Wpływ asymetrii informacji w przypadku tego drugiego okresu ocenia się jako znacznie niższy, natomiast podkreśla się znaczenie czynników związanych z kontrolą (zwłaszcza korzyści płynące z kontroli dla zarządzających) czy też czynnikami behawioralnymi ${ }^{13}$.

\section{Teorie niemieszczące się w klasyfikacji Alexandra Ljungqvista}

Poza klasyfikacją teorii przedstawiona przez A. Ljungqvista znaleźć można koncepcje, które trudno zaliczyć do którejkolwiek z przedstawionych wyżej teorii, a które prezentują interesującą perspektywę na rynek IPO.

Opisane wcześniej teorie odnosiły się przede wszystkim do rynku amerykańskiego i skupiały się na czynnikach ekonomicznych. Jednakże szczególnie w krajach rozwijajacych się i przechodzaccych w ciagu ostatnich dekad transformację ustrojowa, znaczna część pierwotnych ofert publicznych dotyczyła przedsiębiorstw państwowych, które prywatyzowano przez wprowadzenie ich

${ }^{11}$ T. Loughran, J. Ritter, Why has IPO underpricing changed over time?, „Financial Management" 2004, s. 5-37.

${ }^{12}$ K. Rock, op. cit.

${ }^{13}$ T. Loghran, J. Ritter, op. cit. 
akcji do publicznego obrotu. W takich przypadkach, jak wskazuje literatura ${ }^{14}$, poza czynnikami typowo ekonomicznymi duże znaczenie mają również motywy pozaekonomiczne, zwłaszcza polityczne. Jest to sytuacja charakterystyczna dla Polski, dlatego poniżej zostanie przedstawiona najpopularniejsza teoria uwzględniająca czynniki pozaekonomiczne.

W roku 2002 Bruno Bias i Enrico Perotti ${ }^{15}$ jako pierwsi wzbogacili modele oparte na czynnikach ekonomicznych, dodając do nich czynnik polityczny. Proces prywatyzacji prowadzony jest zwykle przez odpowiedni resort rządowy; w przypadku Polski było to Ministerstwo Skarbu Państwa. Dlatego na sama prywatyzację dość znaczacy wpływ ma charakter polityki prowadzonej przez rząd. W swojej pracy B. Bias i E. Perotti dzielą politykę rządową na dwa typy: populistyczna oraz prorynkowa. Rząd populistyczny w odniesieniu do prywatyzacji przedsiębiorstw państwowych charakteryzuje się dążeniem do maksymalizacji wpływów ze sprzedaży udziałów, w czym pomaga oferowanie dużych pakietów akcji. Co ciekawe, w tym samym czasie stara się zachować taki udział w strukturze własnościowej, który pozwoli zachować wpływ na działalność spółki. Natomiast rząd prorynkowy w sytuacji prywatyzacji podmiotów państwowych będzie starał się wspierać ideę własności prywatnej przez stopniową sprzedaż całości akcji w niedużych pakietach.

Kolejna kwestią jest ustalenie ceny emisyjnej. Rząd prorynkowy będzie oferował akcje z dyskontem, z kolei - populistyczny ustali cenę blisko wartości wewnętrznej akcji, aby wpływy z prywatyzacji były możliwie najwyższe. Ponadto w przypadku rządu prorynkowego prywatyzacja przeprowadzona $\mathrm{z}$ dyskontem i kierowana w dużej mierze do inwestorów indywidualnych, stanowiących zazwyczaj klasę średnia, pozwala na zdobycie poparcia tej właśnie grupy wyborców. Co z kolei w naturalny sposób zwiększa szanse na reelekcję.

Dodatkowo warto jeszcze wspomnieć o innych koncepcjach związanych ze zjawiskiem ponadprzeciętnych stóp zwrotu występujących przy debiucie giełdowym, które sformułowane zostały na podstawie wcześniej przeprowadzonych badań empirycznych. Pierwsza z nich wskazuje na proces budowy księgi popytu przy wprowadzaniu spółki na giełdę jako mający istotny wpływ na późniejszą stopę zwrotu w dniu debiutu. Mianowicie zmiany cen w trakcie book buildingu $\mathrm{w}$ stosunku do przyjętego wstępnie przedziału widełkowego maja znaczący wpływ na późniejszą stopę zwrotu przy debiucie ${ }^{16}$. Badania wykazały, że korekty cen powyżej ustalonego przedziału skutkują wyższymi stopami zwrotu przy debiucie. Odpowiednio, korekty poniżej cenowego przedziału wpływają negatywnie na poziom stóp zwrotu.

Z kolei liczne badania prowadzone w zakresie cykliczności rynku IPO pozwoliły na sformułowanie pewnych teorii dotyczaccych tzw. poziomu rozgrzania rynku. Poddając badaniu rynek pierwszych ofert publicznych w szerszym zakresie czasowym (około 20-letnim), można go podzielić ze względu na kryterium aktywności emitentów. Zatem w okresach charakteryzujących się dużą

${ }^{14}$ B. Bias, E. Perotti, Machiavellan privatization, „American Economic Review” 92, 2002.

15 Ibidem

${ }^{16}$ D. J. Bradley, B. D. Jordan, Partial adjustment to public information and IPO underpricing, „The Journal of Financial and Quantitative Analysis” 37, 2002. 
liczbą debiutów odnotowuje się wyższe stopy zwrotu, niż gdy aktywność na tym rynku jest niska. Teoria ta nosi nazwę hot issue market hypothesis (hipoteza rozgrzanego rynku ofert publicznych).

\section{KONCEPCJA I ZAŁOŻENIA BADANIA}

\section{Charakterystyka próby badawczej}

Chcąc ustalić, które z przedstawionych wcześniej teorii znajdują praktyczne zastosowanie na polskim rynku akcji, postanowiono podjąć badanie empiryczne. Jego zakres czasowy obją lata 2007-2016. Pozwoliło to z jednej strony zebrać odpowiednią liczbę obserwacji, a z drugiej - objąć praktycznie pełen cykl koniunkturalny. Kolejnym krokiem było ustalenie zakresu debiutów, które zostaną objęte badaniem. Pierwszym założeniem na tym polu było ograniczenie badania do rynku głównego GPW, co oznacza wyłączenie z próby badawczej podmiotów debiutujących na rynku alternatywnym - NewConnect. Z badania wyłączono również debiuty, które mimo że odbyły się na rynku głównym, to miały charakter przejścia z rynku NewConnect, oraz debiuty o charakterze tzw. cross-listing, czyli takie, które odbyły się na kilku parkietach giełdowych równolegle. Po uwzględnieniu powyższych ograniczeń ostateczna próba objęta badaniem liczy 200 debiutów giełdowych, z lat 2007-2016. Tabela 1 przedstawia liczbę debiutów w poszczególnych latach.

Tabela 1

Liczba debiutów objętych badaniem w latach 2007-2016

\begin{tabular}{|c|c|c|}
\hline Rok & $\begin{array}{c}\text { Liczba debiutów } \\
\text { objętych badaniem }\end{array}$ & $\begin{array}{c}\text { Udział w całkowitej liczbie } \\
\text { debiutów objętych badaniem }\end{array}$ \\
\hline 2007 & 66 & $33,00 \%$ \\
\hline 2008 & 23 & $11,50 \%$ \\
\hline 2009 & 11 & $5,50 \%$ \\
\hline 2010 & 19 & $9,50 \%$ \\
\hline 2011 & 22 & $11,00 \%$ \\
\hline 2012 & 12 & $6,00 \%$ \\
\hline 2013 & 11 & $5,50 \%$ \\
\hline 2014 & 11 & $5,50 \%$ \\
\hline 2015 & 14 & $7,00 \%$ \\
\hline 2016 & 11 & $5,50 \%$ \\
\hline Łącznie & $\mathbf{2 0 0}$ & $\mathbf{1 0 0} \%$ \\
\hline
\end{tabular}

Źródło: opracowanie własne. 
Dość znamienny jest fakt, że liczby debiutów objętych badaniem w poszczególnych latach dość znacząco się pomiędzy sobą różnią. Liczba debiutów w latach 2009, 2010, 2012, 2013 i 2014 łącznie była niższa niż w samym roku 2007.

Badana próba cechowała się dużą różnorodnościa, zarówno w zakresie wielkości przeprowadzonej oferty, jak i stóp zwrotu w dniu debiutu. Wielkość oferty jest wyrażoną w złotych wartość ogółu akcji objętych ofertą, zarówno tych nowo emitowanych, jak i tych wcześniej już wchodzących w skład kapitału zakładowego spółki. Z kolei stopa zwrotu z dnia giełdowego debiutu stanowi skorygowany o zmianę WIG w dniu debiutu, przyrost lub spadek wartości ceny na zamknięcie w dnia debiutu wobec ustalonej wcześniej ceny emisyjnej. Stopa zwrotu wyrażona została następującym wzorem:

$$
I R_{i, t}=\frac{P_{i, t}}{P E_{t}}-1,
$$

gdzie:

$P_{i, t}$ - cena akcji (lub praw do akcji) na zamknięcie notowań w dniu debiutu giełdowego,

$P E_{t}$ - cena emisyjna akcji $\mathrm{PE}_{\mathrm{t}}$ zawarta $\mathrm{w} i$-tej ofercie.

Natomiast skorygowanie obliczonej powyższym wzorem stopy zwrotu, odbywa się w następujący sposób:

gdzie:

$$
I A R_{i, t}=I R_{i, t}-I R M_{i, t}
$$

$I R_{i, t}$ - stopa zwrotu w dniu debiutu (wyznaczona we wcześniej przedstawionym wzorze),

$I R M_{i, t}$ - dzienna stopa zwrotu z indeksu WIG w dniu debiutu danej spółki na giełdzie.

Tabela 2 przedstawia, jak wspomniane wcześniej cechy rozkładały się w badanej próbie.

Tabela 2

Podstawowe charakterystyki próby badawczej

\begin{tabular}{|l|c|c|c|c|}
\hline \multicolumn{1}{|c|}{ Cecha oferty } & $\begin{array}{c}\text { Wartość } \\
\text { najniższa }\end{array}$ & $\begin{array}{c}\text { Wartość } \\
\text { najwyższa }\end{array}$ & Mediana & Średnia \\
\hline $\begin{array}{l}\text { Wielkość oferty } \\
\text { (w zl) }\end{array}$ & 135151,00 & 8068542812,50 & 52965000,00 & 332265183,34 \\
\hline $\begin{array}{l}\text { Stopa zwrotu } \\
\text { w dniu debiutu }\end{array}$ & $-98,78 \%$ & $161,42 \%$ & $4,30 \%$ & $7,89 \%$ \\
\hline
\end{tabular}

Źródło: opracowanie własne. 
Różnice pomiędzy skrajnymi wartościami w przypadku wielkości oferty są bardzo duże. Spółka, która przy okazji debiutu pozyskała najmniej środków, była spółka IZNS Iława, która z planowanych 9,7 mln zł zebrała od inwestorów jedynie nieco ponad 135 tys. zł. Jest to przypadek spółki, która poniosła większe koszty związane z przeprowadzeniem pierwszej oferty publicznej, niż pozyskała z niej środków. Na drugim biegunie znalazła się spółka PZU SA, która jest przykładem jednej z największych prywatyzacji dokonanych w Polsce. PZU ze swojej pierwszej oferty publicznej akcji pozyskał znacznie ponad 8 mld złotych. Jest to rekordowa suma w historii GPW w Warszawie. Mediana w badanej próbie wyniosła 51,6 mln zł przy średniej na poziomie niecałych $365 \mathrm{mln}$ zł.

Natomiast w zakresie skorygowanych stóp zwrotu z dnia debiutu najniższa wartość wyniosła -98,78\%. Tak słaby wynik w dniu swojego pierwszego notowania na warszawskiej giełdzie osiagnęła spółka Wola Info. Z kolei aż $161,42 \%$ pozwoliła zarobić inwestorom spółka Petrolinvest. Średnia wartość skorygowanej stopy zwrotu osiagniętej w dniu debiutu wyniosła w badanej próbie $7,89 \%$, a mediana - 4,30\%. Biorąc pod uwagę średnio dwu- trzytygodniowy okres zamrożenia kapitału związany $\mathrm{z}$ udziałem $\mathrm{w}$ ofercie, można uznać, że inwestowanie w spółki debiutujące jest efektywną formą alokacji kapitału.

\section{Metodologia badania}

Badana grupa debiutów giełdowych charakteryzowała się średnią wartością skorygowanej stopy zwrotu $\mathrm{w}$ dniu debiutu na poziomie $7,89 \%$, natomiast mediana tej cechy wyniosła $4,30 \%$. Na tej podstawie można wnioskować o wyraźnym niedowartościowaniu publicznych ofert akcji na poziomie ogółu badanych spółek debiutujących na warszawskiej giełdzie.

Celem niniejszego opracowania jest ustalenie, które z wybranych (na podstawie przedstawionych wcześniej teorii) czynników miały statystycznie istotny wpływ na rzeczone niedowartościowanie oraz jaki był ich wartościowy wpływ na wysokość skorygowanych stóp zwrotu. Czynniki te ujęto w postaci zmiennych objaśniających w równaniu analizy regresji wielorakiej, w którym zmienną objaśniana stanowiła skorygowana stopa zwrotu z dnia debiutu. Parametry modelu zostały oszacowane klasyczną metodą najmniejszych kwadratów.

\subsection{Zmienne wykorzystane $w$ modelu analizy regresji wielorakiej}

Dobór zmiennych determinowany był wcześniejszymi badaniami przeprowadzonymi na polskim rynku pierwotnych ofert publicznych. Pozwoliło to na sprawdzenie aktualności wniosków płynących z wcześniejszych prac, jak również obserwacji ewentualnych zmian, jakie zaszły w zakresie niedowartościowania ofert publicznych na polskim rynku akcji. Poniżej zamieszczono zestawienie zmiennych wykorzystanych w modelu, jak również sposób ich kalkulacji: 
- skorygowana o dzienną zmianę WIG stopa zwrotu stanowiąca różnicę pomiędzy ceną emisyjną akcji a jej ceną z zamknięcia notowań w dniu debiutu giełdowego;

- wartość danej oferty wyrażona jako logarytm naturalny wartości oferty;

- wartość oferty publicznej w stosunku do sumy wartości kapitałów własnych;

- udział inwestorów indywidualnych w ofercie wyrażony jako iloraz liczby akcji przydzielonych inwestorom indywidualnym oraz ogólnej liczby akcji objętych oferta publiczna;

- stopę redukcji zapisów w transzy dla inwestorów indywidualnych, wskazujący procentowo na redukcję pierwotnie złożonych zapisów na oferowane akcje;

- udział inwestorów indywidualnych w przeprowadzonej ofercie, będący ilorazem wartości transzy przeznaczone dla inwestorów indywidualnych i wartości całej oferty;

- zmienną binarną określająca, czy dana spółka była własnością Skarbu Państwa, która przybierała wartość 1 dla prywatyzowanych spółek państwowych, natomiast $0 \mathrm{w}$ przypadku przedsiębiorstw prywatnych;

- stopień „rozgrzania” rynku pierwotnych ofert publicznych, mierzony za pomocą kroczącej średniej stóp zwrotu z pięciu, wcześniejszych, debiutów giełdowych.

\subsection{Hipotezy badawcze}

Każda z przedstawionych wcześniej zmiennych miała na celu sprawdzenie hipotez badawczych, których treść sformułowano zgodnie z opisanymi wcześniej teoriami:

H I: Zgodnie z teoriami związanymi z asymetrią informacji, im niższa jakość i pewność informacji dotyczących oferty, tym wyższy poziom niedowartościowania spółki w dniu debiutu. W dotychczas przeprowadzonych badaniach jako miernik poziomu asymetrii informacji stosowano zwykle wartość oferty. Wynika to z przekonania, że duże spółki cechują się większą przejrzystościa, a dostęp do ich danych finansowych jest zwykle pełniejszy niż w przypadku mniejszych przedsiębiorstw. Warto zaznaczyć, że w praktyce badawczej uzyskiwane wyniki zdecydowanie wskazują na statystyczną istotność zależności między stopą zwrotu uzyskaną w dniu giełdowego debiutu a wartością oferty. W użytym przy badaniu modelu użyto logarytm naturalny wielkości oferty ze względu na skalę różnic wartości zmiennej. Dlatego pierwsza z hipotez została sformułowana w sposób następujący: Pomiędzy skorygowaną o zmianę WIG w tym dniu stopą zwrotu (IR) a wielkością oferty (Offer_size) zachodzi zależność o charakterze negatywnym.

H II: Nawiązując do teorii sygnałów - właściciele spółki debiutującej na giełdzie posiadaja pełniejszą wiedzę co do jej rzeczywistej, wewnętrznej wartości niż inwestorzy zewnętrzni. W modelach stworzonych przez I. Welcha ${ }^{17}$

${ }^{17}$ I. Welch, op. cit. 
firmy charakteryzujące się wysoka jakością wykazują tendencję do oferowania stosunkowo niedużej części dotychczasowego kapitału własnego spółki $\mathrm{w}$ ofercie publicznej. Jednocześnie celowo zaniżają one cenę emisyjna poniżej jej wartości wewnętrznej, dając tym samym inwestorom jasny sygnał o wysokiej jakości danej oferty. W założeniu pozwala to w przyszłości uzyskiwać wyższe ceny przy okazji kolejnych emisji akcji. W związku z powyższym zdecydowano się na sprawdzenie następująco sformułowanej hipotezy: Pomiędzy udziałem dotychczasowego kapitału własnego w pierwotnej ofercie (Share_of_equity) a skorygowaną stopą zwrotu z dnia debiutu (IR) zachodzi negatywna zależność.

H III: Zgodnie z teoria reelekcji, dotycząca otoczenia politycznego ${ }^{18}$, odpowiednio skonstruowana oferta publiczna dotyczaca prywatyzowanej przez giełdę spółki pozwala na zwiększenie swoich szans w ubieganiu się o reelekcję. W sytuacji alokacji stosunkowo dużej części oferty pośród inwestorów indywidualnych, w domyśle obywateli i wyborców, i przy towarzyszącej w tym samym czasie poziomie ceny emisyjnej ustalonym poniżej wartości wewnętrznej, wyborcy uzyskują dodatkowe korzyści materialne, biorąc udział w ofercie prywatyzowanej spółki. Natomiast w odniesieniu do debiutujących na giełdzie spółek prywatnych wskazać można na chęć zwiększenia liczby akcji w wolnym obiegu, co w fazie notowań pozwoli na większa płynność waloru, a tym samym jego wyższy kurs. W tym celu emitenci przydzielają względnie większy pakiet inwestorom indywidualnym, dodatkowo zachęcając ich do aktywniejszego uczestnictwa w ofercie. Hipoteza brzmi zatem następujacco: Oferty charakteryzujące się dużym udziałem inwestorów indywidualnych w ofercie wykazuja zazwyczaj wyższe stopy zwrotu w dniu debiutu, co powoduje, że istnieje istotna statystycznie dodatnia korelacja pomiędzy skorygowaną o zmianę WIG stopa zwrotu w dniu debiutu (IR) a udziałem inwestorów indywidualnych w ofercie (Individual).

H IV: Kolejna z postawionych hipotez nawiąuje do zjawiska asymetrii informacji na poziomie samych inwestorów, wywodzącego się z teorii winner's curse $^{19}$. Według tej koncepcji na rynku dochodzi do sytuacji, w których inwestorzy posiadający szerszą wiedzę o danym papierze wartościowym wybieraja jedynie te emisje, które pozwolą wygenerować dodatnią stopę zwrotu w dniu debiutu. Sprawia to, że inwestorzy gorzej poinformowani obejmuja akcje w ofertach o gorszej jakości, ponieważ nie są w stanie skutecznie ocenić jakości danej oferty. W takiej sytuacji można założyć, że inwestorzy gorzej poinformowani obejmą akcje przede wszystkim jakościowo gorszych ofert, natomiast ci o lepszym dostępie do informacji będą w stanie zainwestować swój kapitał w spółki cechujące się lepszą jakością. Zmienną która wydaje się w największym stopniu nadawać do weryfikacji tej hipotezy, jest stopa redukcji zapisów $\mathrm{w}$ transzy przeznaczonej dla inwestorów indywidualnych. Hipoteza IV brzmi:

18 B. Bias, E. Perotti, op. cit.

19 K. Rock, op. cit. 
Pomiędzy stopą redukcji zapisów w transzy przeznaczonej dla inwestorów indywidualnych (Redrate) a skorygowaną stopa zwrotu w dniu debiutu giełdowego (IR) zachodzi zależność o charakterze pozytywnym.

H V: Jedna z funkcji pełnionych przez prywatyzacje stanowi zwiększenie świadomości inwestycyjnej wśród obywateli ${ }^{20}$. Ma to na celu przekonanie społeczeństwa do aktywnego udziału w rynku kapitałowym, co w domyśle przynieść ma korzyści zarówno obywatelom, jak i samym spółkom. Pierwsza z tych grup uzyska dodatkowe środki, które przeznaczy na bieżąca konsumpcję, jak i oszczędności gromadzone w perspektywie emerytury. Natomiast spółki poszerzą bazę potencjalnych inwestorów gotowych nabyć akcje w ramach kolejnych emisji. Większy udział społeczeństwa w inwestowaniu giełdowym prowadzi również do wzrostu płynności danego rynku, co przekłada się na wyceny spółek giełdowych i przynosi korzyści ogółowi uczestników rynku. Rola państwa w tym zakresie jest duża, a jego głównym narzędziem jest odpowiednie przygotowanie ofert publicznych spółek prywatyzowanych. Dlatego tego typu oferty powinny być odpowiednio reklamowane, ale przede wszystkim cechować się pewnym dyskontem ceny emisyjnej wobec wartości wewnętrznej, co przyniesie obywatelom wymierne korzyści finansowe, które mogą na dłużej przyciagnąc ich do rynku giełdowego. Postawiono zatem hipotezę brzmiąca następująco: Spółki będące przed debiutem giełdowym własnością Skarbu Państwa cechują się przeciętnie wyższą stopa zwrotu z inwestycji niż spółki prywatne, a więc zachodzi pozytywna zależność między statusem spółki Skarbu Państwa (Public_company) a skorygowaną stopa zwrotu w dniu debiutu (IR).

H VI: Rynek ofert IPO cechuje się swego rodzaju cyklicznościa, okresy wyższych stóp zwrotu $\mathrm{w}$ dniu debiutu przeplatają się z fazami niskiego zwrotu z debiutu, które wiążą się również z aktywnością mierzoną za pomoca ilości debiutów w danym okresie. Zatem można na tej podstawie wnioskować o wyższych stopach zwrotu w przypadku spółek debiutujących w okresach, kiedy to rynek pierwotnych ofert publicznych jest mocno „rozgrzany”. Jest to hipoteza wywodząca się bezpośrednio z teorii hot isssue markets ${ }^{21}$. Zmienna, która została użyta $\mathrm{w}$ badaniu, mająca oddać stopień rozgrzania rynku, jest średnia krocząca ze skorygowanych stóp zwrotu z pięciu ostatnich debiutów giełdowych. Na podstawie powyższego sformułowano następująca hipotezę: Pomiędzy faza cyklu, w jakiej znajduje się rynek ofert publicznych, która mierzona jest średnią ze stóp zwrotu z pięciu debiutów poprzedzających dany (Heat_of_the_market), a skorygowana stopa zwrotu w dniu debiutu (IR) zachodzi korelacja o charakterze pozytywnym.

${ }^{20}$ B. Bias, E. Perotti, op. cit.

${ }^{21}$ R. G. Ibbotson, Price performace of common stock new issues, „Journal of Financial Economics” 2, 1975 . 


\section{ANALIZA KORELACJI I REGRESJI}

Wykorzystane przy formułowaniu hipotez zmienne zostały przedstawione w tabeli 3 wraz z odpowiadającymi im wartościami średnich i median.

Tabela 3

Średnie wartości zmiennych wykorzystanych w modelu

\begin{tabular}{|l|c|c|c|}
\hline \multicolumn{1}{|c|}{ Nazwa zmiennej } & Średnia & Mediana & $\begin{array}{c}\text { Odchylenie } \\
\text { standardowe }\end{array}$ \\
\hline IR & $7,89 \%$ & $4,30 \%$ & 0,2243 \\
\hline Offer size & 17,93 & 17,76 & 1,6448 \\
\hline Share of equity & $46,20 \%$ & $45,21 \%$ & 0,2319 \\
\hline Individual & $22,56 \%$ & 20,00 & 0,15065 \\
\hline Redrate & $60,61 \%$ & $69,34 \%$ & 0,31 \\
\hline Public company & - & - & - \\
\hline Heat of the market & $8,68 \%$ & $5,34 \%$ & 0,1426 \\
\hline
\end{tabular}

Źródło: opracowanie własne.

Następnym przeprowadzonym w badaniu krokiem było sprawdzenie siły korelacji pomiędzy poszczególnymi zmiennymi.

\section{Tabela 4}

Macierz korelacji zachodzących pomiędzy poszczególnymi zmiennymi

\begin{tabular}{|l|c|c|c|c|c|c|}
\cline { 2 - 7 } \multicolumn{1}{c|}{} & Redrate & $\begin{array}{c}\text { Share } \\
\text { of equity }\end{array}$ & Offer size & $\begin{array}{c}\text { Indivi- } \\
\text { dual }\end{array}$ & $\begin{array}{c}\text { Public } \\
\text { company }\end{array}$ & $\begin{array}{c}\text { Heat } \\
\text { of the } \\
\text { market }\end{array}$ \\
\hline Redrate & 1,000 & 0,221 & 0,117 & $-0,072$ & $-0,095$ & 0,423 \\
\hline Share of equity & 0,221 & 1,000 & 0,174 & 0,142 & $-0,079$ & 0,205 \\
\hline Offer size & 0,117 & 0,174 & 1,000 & $-0,186$ & 0,472 & 0,075 \\
\hline individual & $-0,072$ & 0,142 & $-0,186$ & 1,000 & 0,021 & $-0,002$ \\
\hline Public company & $-0,095$ & $-0,079$ & 0,472 & 0,021 & 1,000 & $-0,077$ \\
\hline $\begin{array}{l}\text { Heat of the } \\
\text { market }\end{array}$ & 0,423 & 0,205 & 0,075 & $-0,002$ & $-0,077$ & 1,000 \\
\hline
\end{tabular}

Źródło: opracowanie własne. 
Analizując powyższe dane, należy zwrócić uwagę na wartości skrajne. Najsilniejsza dodatnia korelacja występuje pomiędzy zmiennymi opisującymi wielkość oferty a zmienną binarną wskazująca, czy dana spółka była przed debiutem własnościa prywatną czy też Skarbu Państwa. Wyniosła ona 0,472. Natomiast najmocniej negatywnie skorelowane zmienne stanowiły udział inwestorów indywidualnych w ofercie publicznej oraz wartość tej oferty.

Po sprawdzeniu korelacji zachodzących pomiędzy zmiennymi kolejnym krokiem było przeprowadzenie analizy regresji na podstawie zgromadzonych danych. Badanie przeprowadzone zostało w programie IBM SPSS Statistics ver. 21 . Wyniki analizy regresji zostały przedstawione w poniższej tabeli. Pogrubioną czcionką zaznaczono wartości p-value poniżej 0,05 .

Tabela 5

Model regresji przedstawiający czynniki kształtujące poziom skorygowanej stopy zwrotu w dniu debiutu

\begin{tabular}{|l|c|c|}
\hline \multicolumn{1}{|c|}{ Zmienne objaśniające } & Współczynnik & $\boldsymbol{p}$-value \\
\hline Przecięcie & 0,085 & 0,687 \\
\hline Redrate & 0,260 & $\mathbf{0 , 0 0 1}$ \\
\hline Share_equity & $-0,119$ & 0,132 \\
\hline Ln_scale_offer & $-0,003$ & 0,783 \\
\hline Individual & $-0,306$ & $\mathbf{0 , 0 1 1}$ \\
\hline Public_company & 0,032 & 0,711 \\
\hline Heat_of_the_market & 0,268 & $\mathbf{0 , 0 2 5}$ \\
\hline $\mathrm{R}^{2}$ & 0,208 & \\
\hline Skorygowany $\mathrm{R}^{2}$ & 0,184 & \\
\hline
\end{tabular}

Źródło: opracowanie własne.

Tak uzyskane wyniki posłużyć mogły następnie do przeprowadzenia weryfikacji wcześniej postawionych hipotez badawczych.

Badanie nie wykazało istotnego wpływu wielkości oferty, mierzonej jako logarytm naturalny wartości oferowanych akcji, na wielkość skorygowanej stopy zwrotu w dniu debiutu. Powoduje to odrzucenie hipotezy pierwszej, odwołujacej się do teorii asymetrii informacji na rynku pierwotnych ofert publicznych. Wyniki badań przeprowadzonych dotychczas na polskim rynku akcji nie były w przypadku tak postawionej hipotezy jednoznaczne. Wolfgang Aussenegg ${ }^{22}$ wykazał w swoim badaniu istotną pozytywną zależność, co było wbrew oczekiwanemu rezultatowi. Z kolei badanie Esmeraldy Lyn i Edwarda Zychowi$\mathrm{cza}^{23}$ nie wskazywało na żaden istotny wpływ wielkości oferty na stopę zwrotu

${ }^{22}$ W. Aussenegg, Going Public in Poland: Case-by-Case Privatizations, Mass Privatizations and Private Sector IPO, Vienna University of Technology, Austrian Working Group on Banking and Finance, Vienna 1999.

${ }^{23}$ E. Lyn, E. J. Zychowicz, The Performance of new equity offerings in Hungary and Poland, „Global Finance Journal” 14, 2003. 
w dniu debiutu. Natomiast w kolejnym badaniu, przeprowadzonym przez Leszka Czapiewskiego, Tomasza Jewartowskiego, Michała Kałdońskiego i Jacka Mizerkę ${ }^{24}$, wykazano istotną negatywną zależność, co było też wynikiem najczęściej spotykanym w badaniach dotyczących rynków zagranicznych.

Druga z postawionych hipotez, nawiązująca do teorii sygnałów, również ze względu na brak istotności została odrzucona. W. Aussenegg w swoim badaniu również nie znalazł istotnej zależności między omawianymi zmiennymi. Teoria sygnałów zweryfikowana została również w badaniu przeprowadzonym przez L. Czapiewskiego, T. Jewartowskiego, M. Kałdońskiego i J. Mizerkę, którzy używając zmiennej wskazującej na udział dotychczasowych akcjonariuszy w strukturze głosów po przeprowadzonej ofercie, wykazali pozytywny jej wpływ na skorygowaną stopę zwrotu w dniu debiutu giełdowego. Można zatem założyć, że w przypadku badania, o którym mowa, stawiana w pracy hipoteza nie została odrzucona.

Kolejna ze stawianych $\mathrm{w}$ niniejszej pracy hipotez, odnoszaca się do teorii głoszącej pogląd o pozytywnym wpływie rosnącego udziału inwestorów indywidualnych w ofercie na stopy zwrotu w dniu debiutu, nie znalazła podstaw do odrzucenia. Jest to wynik zbieżny z wcześniej przeprowadzonymi na naszym rynku badaniami. Jednak nie daje to potwierdzenia teorii reelekcji zaprezentowanej przez B. Biasa i E. Perottiego odnoszącej się do państwowych spółek prywatyzowanych.

Hipoteza czwarta, odnosząca się również do teorii asymetrii informacji, a konkretnie do zjawiska winner's curse $e^{25}$ mierzonego wpływem stopy redukcji zapisów w transzy dla inwestorów indywidualnych na stopę zwrotu z dnia debiutu, nie znalazła podstaw do odrzucenia. Warto zaznaczyć, że istotny statystycznie wpływ występuje w obu zbadanych podgrupach. W przeprowadzonych dotychczas na polskim rynku ofert publicznych badaniach jedynie w modelu użytym przez L. Czapiewskiego, T. Jewartowskiego, M. Kałdońskiego i J. Mizerkę weryfikowana była teoria winner's curse. Wspomniane badanie również nie dało podstaw do odrzucenia podobnie postawionej hipotezy, znajdując istotnie statystyczny pozytywny wpływ stopy redukcji zapisów na stopę zwrotu w dniu debiutu.

Z badania wynika ponadto, że prywatyzowane spółki Skarbu Państwa nie wykazywały istotnie statystycznie wyższych stóp zwrotu z debiutu giełdowego, co każe odrzucić hipotezę piątą.

Ostatnia $\mathrm{z}$ weryfikowanych $\mathrm{w}$ badaniu hipotez odnosiła się do teorii rozgrzanego rynku ofert publicznych, teorii związanej ze swoistą cyklicznościa tego rynku. Teoria ta znalazła swoje odbicie w uzyskanych wynikach, które na poziomie całej przebadanej grupy, jak i w podgrupie IPO, gdzie uzyskano istotny statystycznie, pozytywny wpływ fazy, w jakiej znajduje się rynek pierwotnych ofert publicznych (mierzony średnią stóp zwrotu z pięciu poprzedzających debiutów) na stopy zwrotu uzyskiwane w dniu debiutu giełdowego. W odniesieniu do badań historycznych z polskiego rynku należy wspomnieć ponownie o pracy L. Czapiewskiego, T. Jewartowskiego, M. Kałdońskiego

${ }^{24}$ L. Czapiewski et al., Determinanty natychmiastowych stóp zwrotu $z$ akcji spótek Skarbu Państwa dokonujacych pierwotnych ofert publicznych, Wyd. UEP, Poznań 2011.

${ }^{25}$ K. Rock, op. cit. 
i J. Mizerki, w której nie znaleziono jednak żadnego związku pomiędzy faza, $\mathrm{w}$ jakiej znajduje się rynek ofert pierwotnych, a stopami zwrotu uzyskiwanymi w dniu debiutu giełdowego. Należy jednak zaznaczyć, że odmiennie skonstruowano zmienną opisująca koniunkturę rynkowa.

\section{PODSUMOWANIE}

Celem niniejszego artykułu była próba wskazania, które z wybranych czynników wykazuja istotny wpływ na niedowartościowanie pierwotnych ofert publicznych przeprowadzonych w Polsce. Jednocześnie stworzyło to możliwość sprawdzenia w praktyce pewnych koncepcji teoretycznych próbujących wyjaśnić zjawisko niedowartościowania akcji w ofertach publicznych. Realizacja celu została dokonana poprzez badanie przeprowadzone na 200 ofertach publicznych dokonanych w latach 2007-2016 na GPW w Warszawie. Uzyskane wyniki badania pozwoliły na jednoznaczne wskazanie, że w przypadku przeprowadzonych na polskim rynku akcyjnym pierwotnych ofert publicznych dochodzi do zjawiska niedowartościowania.

Przeciętny poziom niedowartościowania ofert publicznych objętych badaniem wyniósł 7,89\% (przy medianie 4,30\%). Odnoszac ten wynik do badań przeprowadzonych na polskim rynku w przeszłości, zaobserwować można, że skala niedowartościowania jest obecnie wyraźnie niższa ${ }^{26}$.

Ponadto przeprowadzone badanie pozwoliło na weryfikację postawionych hipotez, a jego wyniki potwierdziły praktyczne znaczenie kilku teorii. Koncepcja winner's curse zakładająca, że lepsze jakościowo oferty cechuja się większym niedowartościowaniem, znalazła swoje odzwierciedlenie przez istotny statystycznie wpływ stopy redukcji w transzy dla inwestorów indywidualnych na stopę zwrotu w dniu debiutu. Teoria rozgrzanego rynku, odnosząca się do cykliczności rynku ofert publicznych jest kolejna, która została pozytywnie zweryfikowana $\mathrm{w}$ toku badania. Udało się również wykazać, że oferty o stosunkowo wyższym udziale inwestorów indywidualnych charakteryzują się większym niedowartościowaniem. Stanowi to potwierdzenie teorii Lawrence'a Benveniste i Paula Spindta odnoszacej się do wpływu asymetrii informacji zachodzącej pomiędzy poszczególnymi grupami inwestorów biorących udział w ofercie. Jednocześnie w wyniku przeprowadzonej weryfikacji odrzucono hipotezę mówiąca o wyższym poziomie niedowartościowania $\mathrm{w}$ przypadku ofert przeprowadzanych przez Skarb Państwa, jak również tę wskazującą na dodatni wpływ wartości oferty na skalę jej niedowartościowania. Wielkość udziału dotychczasowych właścicieli w strukturze akcjonariatu po przeprowadzeniu oferty także okazała się nie mieć istotnego statystycznie wpływu na skalę niedowartościowania.

mgr Albert Trapczyński

Uniwersytet Ekonomiczny w Poznaniu

a.trapczynski@gmail.com

${ }^{26}$ W badaniu przeprowadzonym na polskim rynku IPO w latach 1991-1997 średnie niedowartościowanie wyniosło 19,8\% przy medianie na poziomie 12,6\%. W. Aussenegg, op. cit. 


\title{
INITIAL PUBLIC OFFERINGS UNDERPRICING \\ IN THE CONTEXT OF THEORETICAL BACKGROUND
}

\author{
Sum mary
}

The main objective of this paper is to identify which theories regarding the phenomenon of Initial Public Offerings underpricing are applicable to the Polish stock market. To accomplish that goal a study of determinants of IPO underpricing at the Polish stock market between 2007 and 2016 was conducted. Its results indicate that over the study period the average initial adjusted return was $7.89 \%$ which is significantly lower than the value obtained in the previous studies at the Polish market. The strongest determinant of underpricing turned out to be the information asymmetry proxied by the reduction rate in the individual investors tranche. This allowed to confirm the relevance of Kevin Rock's winner's curse theory on the Polish market. These results did not provide grounds for rejecting the hypothesis of the positive influence of the structure of the offer on underpricing, which is in line with another asymmetry theory introduced by Lawrence Benveniste and Paul Spindt. Moreover, the study confirmed the 'hot market issue' hypothesis which indicates that underpricing of IPO is higher in favourable market conditions. On the other hand, the same results rejected the hypothesis of higher underpricing of the privatisation offers as well as the hypothesis of the reliance on the positive impact of scale of the offer on the initial return. 
